\title{
Polyglotism and Identity in Modern-Day Lebanon
}

by Sarya Baladi

\section{Introduction}

Lebanon is known as the true meeting place of Middle Eastern, Arab, and European culture, an incredible mix that is illustrated by the unquestionable and unique polyglotism used daily by both the ancient and the modern Lebanese. ${ }^{1}$ Sélim Abou, a prominent Lebanese philosopher and anthropologist, defines bilingualism in ArabicFrench Bilingualism in Lebanon as "the double language through which the subject, individual or group expresses paradoxically his/her/their unique personality. It therefore appears like a cultural experience, specified by the way it affects the bilingual." "Modern-day Lebanon, embodying Abou's definition of bilingualism, is often referred to as a 'bilingual' or even 'trilingual' country, since the Arabic, French, and English languages are all widely used by the Lebanese. The greeting "Hi! Kifak? Ça va?" is a stereotypical marker of Lebanese linguistic identity as it illustrates the prevalence of this polyglotism and fusion of cultures in the quotidian lives of the people of Lebanon.

Polyglotism is usually not a common phenomenon to occur in a given society. It arises from peaceful or violent outside political intervention, bringing with it a new language that is eventually used by the common people. The people of Mount Lebanon originally spoke Syriac and Aramaic languages, but the multiple invasions by and interactions with different conquering powers led to the introduction of modern Lebanese polyglotism. Arabic was brought to the Levant during the spread of Islam through the Arab conquests of the $7^{\text {th }}$ century and has been used in the Middle East ever since. ${ }^{3}$ The Arabic language is the essence of Islam, the predominant religion of the Middle East, and is therefore used to a certain degree in most Muslim-majority countries. French and English, on the other hand, were always objects of interest among the people of Mount Lebanon, but were only institutionalized in Lebanese society and education as of the $19^{\text {th }}$ century, when Catholic and Protestant missionaries came to the country to educate the Lebanese with Western languages, religions, and values. ${ }^{4}$ Western powers were in general very politically involved in Lebanon, supporting and advocating for ethno-religious groups with the same beliefs: as a result, "France supported Maronite and Catholic communities, Russia supported the Orthodox, and Turkey sided with the Muslims," and minority populations most often were aligned with the Western power looking after them. ${ }^{5}$

With such an incredible combination of different languages, cultures, philosophies, and political identifications, in addition to the increasingly globalized and cosmopolitan world we live in, one can imagine the magnitude of the 'identity crisis' taking place in $21^{\text {st }}$-century Lebanon. Between its Arab heritage and its unquestionable openness to Western influence, the Lebanese are torn between Western and Oriental identification, with a very strong divide between the Christian and Muslim

\footnotetext{
${ }^{1}$ Sélim Abou, Arabic-French Bilingualism in Lebanon, 158

${ }^{2}$ Sélim Abou, Arabic-French Bilingualism in Lebanon, 2

${ }^{3}$ John Esposito, Islam the Straight Path, 46

${ }^{4}$ Deanna Ferree Womack, Lubnani, Libanais, Lebanese: Missionary Education, Language Policy and Identity Formation in Modern Lebanon, 5

${ }^{5}$ Rula Diab, Political and Socio-Cultural Factors in Foreign Language Education-

The Case of Lebanon, 4
} 
populations. Should Lebanon embrace its Mediterranean cosmopolitan multi-cultural nature, by espousing its Phoenician past and Western colonizers? Or, should it rather celebrate Pan-Arabism by rejecting the evils of imperialism and by identifying solely with its Arab, Muslim, and Oriental heritage?

Language plays a vital role in this identity crisis and is a true marker of how Lebanese define themselves, with whom they choose to associate, and how they wish to be viewed by others. In other words, the implicit or explicit choice of language in Lebanon, whether Arabic, French or English, or a combination thereof, is a tool to convey one's political, religious, and cultural views. During the $20^{\text {th }}$ century, this identity crisis led to a strong divide between the Eastern and the Western-oriented Lebanese, especially between Lebanese Christians and Muslims, creating religious sectarianism and spiraling into a civil war.

\section{The Maronites of Mount Lebanon (pre-19 $9^{\text {th }}$ century)}

Lebanon has always been at the crossroads of foreign interventions that have continuously influenced the country's language and culture. Its first true contact with the Western World took place during the Crusades $\left(11^{\text {th }}-13^{\text {th }}\right.$ centuries $)$ between the Frankish Crusaders and the Maronites of Mount Lebanon, a sect of Lebanese Christians in communion with the Roman Catholic Church. When the Frankish Crusaders came to the Holy Land to retake Jerusalem from the Muslims, they helped and supported the Maronites with whom they shared deep religious ties. As a result, the Maronites were thankful to see their land taken by the French, people with whom they were able to make great religious connections, and viewed them as their saviors rather than stereotypical invaders. ${ }^{6}$ Although the Crusaders were eventually expelled from the Levant by Muslim powers, the French and the Maronites maintained this unique relationship of mutual aid and respect; during the Ottoman times, for example, Maronite clergy would be trained in Rome to teach in European universities and in schools in Lebanese Maronite villages. ${ }^{7}$

Lebanon is and always has been home to a plethora of ethno-religious communities, such as Maronite Chistrians, Sunni Muslims, Greek Orthodox Christians, Shia Muslims, Catholic Christians, and Druze. ${ }^{8}$ The Maronites, however, with their long history in the region and their establishment as the majority in Mount Lebanon, developed a very strong connection to the land and came to celebrate it as the haven of Christianity in the Levant. They are, according to Abou, "the first to feel the land - mountain and littoral - as a land and consequently a homeland." ${ }^{\prime 9}$ It was therefore a great milestone when Mount Lebanon gained partial autonomy from the slowly dying Ottoman Empire: thanks to the Réglement organique (Organic Regulation) signed by the Ottoman Empire and France, the Mutasarrifate subdivision was established in 1861 under the governance of a non-Lebanese Christian governor appointed by the Sultan. This gave the Maronites greater room for self-determination and self-identification in their homeland. As a result of the weakening of the Ottomans and the increasing autonomy of the Lebanese, further Western intervention was able to take place in Mount Lebanon, mainly through missionary education.

\footnotetext{
${ }^{6}$ Sélim Abou, Arabic-French Bilingualism in Lebanon, 46

${ }^{7}$ Sélim Abou, Arabic-French Bilingualism in Lebanon, 176

${ }^{8}$ Rula Diab, Political and Socio-Cultural Factors in Foreign Language Education: The Case of Lebanon, 4

${ }^{9}$ Sélim Abou, Arabic-French Bilingualism in Lebanon, 47
} 


\section{Catholic and Protestant Missionary Education in Mount Lebanon}

As Western powers engaged in colonial and expansionist policies throughout the $19^{\text {th }}$ century in Africa and Asia, they recognized the great potential of the Middle East due to its strategic location. The French, in particular, were adamant to further their influence in Mount Lebanon due to their favorable relationship with the Maronites, giving them greater power in the Levant as well as the opportunity to spread their language and culture overseas. The British also saw great value in taking advantage of the dying Ottoman Empire to assert their influence in the region. One of the ways both the French and the British were able to have a substantially positive effect on Lebanese society was through the establishment of Francophone Catholic and Anglophone Protestant missionary schools. These institutions promoted "diverging cultural and political commitments as well as their theological orientations" through the teaching of their own language in the setting of a private school, away from Ottoman and Oriental influences. ${ }^{10}$ Missionary education not only led to greater Western influence in Lebanon, but also to positive relations and mutual understanding between the Lebanese, the French and the British in terms of language, culture, religion and ideals. These schools were viewed very favorably by the Lebanese and eventually came to dominate the educational sphere in metropolitan Lebanon, notably in the capital Beirut. $^{11}$

French and British missionary education gave birth to great Jesuit and Protestant universities that had a substantial impact on the political philosophies the Lebanese were to adopt throughout the $20^{\text {th }}$ century. The French, with the support from the Vatican and the Lebanese Maronite hierarchy, established the Université Saint-Joseph (USJ) in 1881, the most prominent Jesuit Francophone academic research institution in the Levant. ${ }^{12}$ The British, on the other hand, founded the Anglophone Syrian Protestant College in 1866, today known as the American University of Beirut (AUB), which fully adopts the American education system. The AUB came to be known as one the best universities in the region, attracting students and academics from the Middle East and beyond. ${ }^{13}$ The existence of such institutions, most often more celebrated and prestigious than Ottoman public schools or Muslim private schools, played a monumental role in shaping the function and image of France and Great Britain in Lebanon and promoted a positive reputation rather than traditionally negative images these countries have in colonized lands. The French and English languages gained a vital role in Lebanese intellectual and economic life as of the $19^{\text {th }}$ century and became essential to expand one's professional and personal horizons in cosmopolitan Lebanon. Missionary education became the education of the elite, and "the most influential Arab writers of the mid-1800s received their schooling in monasteries and educational centers promoted by the first wave of Catholic missionaries." 14

\footnotetext{
${ }^{10}$ Deanna Ferree Womack, Lubnani, Libanais, Lebanese: Missionary Education, Language Policy and Identity Formation in Modern Lebanon, 6

${ }^{11}$ Deanna Ferree Womack, Lubnani, Libanais, Lebanese: Missionary Education, Language Policy and Identity Formation in Modern Lebanon, 14

${ }^{12}$ Deanna Ferree Womack, Lubnani, Libanais, Lebanese: Missionary Education, Language Policy and Identity Formation in Modern Lebanon, 6

${ }^{13}$ Deanna Ferree Womack, Lubnani, Libanais, Lebanese: Missionary Education, Language Policy and Identity Formation in Modern Lebanon, 6

${ }^{14}$ Deanna Ferree Womack, Lubnani, Libanais, Lebanese: Missionary Education, Language Policy and Identity Formation in Modern Lebanon, 14
} 
With time, these Western languages also made their way to the Lebanese common people, who are fluent speakers of Vernacular Lebanese Arabic; although monolingualism remained common, bilingualism and trilingualism were on the rise. According to a study by the AUB in $1953,42 \%$ of the heads of households in Beirut mastered French and 22\% mastered English. ${ }^{15}$ The acquisition of these languages, however, spread mostly across religious lines, since some ethno-religious Lebanese groups identified with a certain language over another. Catholics and Maronites valued French due to their historical cultural ties to France, and Orthodox Christians were more likely to study English. ${ }^{16}$ Muslims identified more with Modern Standard Arabic, the language of the Qur'an, and tended to be much more critical of Western intervention and colonization. ${ }^{17}$ Although all these groups used Vernacular Lebanese Arabic perfectly in their daily lives, identification with another language besides spoken Arabic became the norm among Lebanese ethno-religious groups.

\section{Francophone Influence in Lebanon}

The French Jesuits truly believed in the role of the Maronites as "defenders of the Catholic faith in 'the Orient"' and did everything in their power to maintain their cultural, religious and political relationship with Lebanese Christians. ${ }^{18}$ As a result, French became the language of education and culture of the Maronite upper class and spread from there to other religious groups, as many Muslim families also chose to send their children to missionary schools throughout the $20^{\text {th }}$ century; consequentially, "the student population in Beirut's Christian schools was three times higher than in Muslim schools" by $1882 .^{19}$

In partnership with Lebanese Arabic, bilingualism developed at all levels of society from educational to governmental institutions. Although many remained monolingual or preferred another language to French for their bilingualism, Arabic-French bilingualism was by far the most prevalent in $20^{\text {th }}$ century Lebanon. This form of bilingualism grew to be extremely engrained in the lives of the Lebanese; it is so prevalent that "it surprises neither the one who talks nor his or her interlocutor." 20 Whereas bilingualism in other countries treats the second language as a dead language, both languages in Lebanon are regarded as modern languages as they are used interchangeably in a single conversation or even in a single sentence. As a result, "a French word often determines an Arabic sentence." ${ }^{21}$ The bilingual Lebanese sees French and Arabic as true components of a unique Lebanese identity and cherishes both: on the one hand, the Vernacular Lebanese Arabic is distinct from other variations of Arabic, and on the other hand, Francophone Lebanese speak French in a very particular manner by rolling the $-r$ and by adding a certain musicality to the language that the French themselves do not employ. ${ }^{22}$ This remarkable bilingualism allows the Lebanese "to express in an original and personal manner these two

\footnotetext{
${ }^{15}$ Youssef Courbage, Une enquête sur la pratique de la langue française au Liban, 2

${ }^{16}$ Rula Diab, Political and Socio-Cultural Factors in Foreign Language Education-

The Case of Lebanon, 4

${ }^{17}$ Rula Diab, Political and Socio-Cultural Factors in Foreign Language Education: The Case of Lebanon, 4

${ }^{18}$ Deanna Ferree Womack, Lubnani, Libanais, Lebanese: Missionary Education, Language Policy and Identity Formation in Modern Lebanon, 8

${ }^{19}$ Deanna Ferree Womack, Lubnani, Libanais, Lebanese: Missionary Education, Language Policy and Identity Formation in Modern Lebanon, 11

${ }^{20}$ Sélim Abou, Arabic-French Bilingualism in Lebanon, 69

${ }^{21}$ Sélim Abou, Arabic-French Bilingualism in Lebanon, 65

${ }^{22}$ Sélim Abou, Arabic-French Bilingualism in Lebanon, 264
} 
languages, meaning innovating them, in perfect knowledge of the cause, in the domain of one language or the other, or both at the same time." 23

Following the disintegration of the Ottoman Empire at the conclusion of World War I, Lebanon was placed under French Mandate by the League of Nations to ensure the development of a successful democracy in the Levant. Lebanon became a parliamentary republic in 1926 and eventually gained its independence in 1943 with a full expulsion of French troops in $1946 .{ }^{24}$ However, French influence was already cemented by the establishment of Greater Lebanon under Henri Gouraud in 1920 at the raging joy of the Maronites, who yearned for a country to themselves as a haven for Christians in the Middle East. Although most non-Western countries viewed France as a colonizing power, exploiting their resources and people for their own economic and political interest, Maronites for the most part did not adhere to this classic anti-colonizer rhetoric. They respected the French and were grateful for their intervention, since, from their point of view, it is thanks them that they were able to maintain their culture and religion in the predominantly Muslim region. Many Maronites became proud Francophones and strong identifiers with the Western way of life; they "[drew] upon views of Jesuit institutions as representing France and Rome and [treated] French as a marker of theo-political self-identification." 25 Their refuge into French culture kept them away from the political project of Pan-Arabism that took over many parts of the Middle East in the $20^{\text {th }}$ century, a philosophy viewed by many Lebanese Christians as a 'Muslim project.'

By identifying with French culture, the Maronites were able to differentiate themselves from the Arabs and Muslims and were able to fully embrace what they considered to be their true polyglot, cosmopolitan Western heritage. Many Maronites did so by refusing to identify as 'Arabs' and embracing, rather, their ancient 'Phoenician' roots; as many viewed it, "Lebanese equals Maronite equals Phoenician." ${ }^{26}$ As Arab nationalism was starting to gain ground towards the end of the $19^{\text {th }}$ century, various excavations throughout the Middle East were being conducted by Western powers, giving fruit to the rediscovery of multiple ancient civilizations, such as the Phoenician civilization. These excavations sparked much interest throughout Arabic-speaking countries for those who did not identify with or felt suppressed by Arab nationalism, notably the Christians in Mount Lebanon. Although Pan-Arabism was a secular project, they tended to view this movement as a means to suppress ethno-religious identities in the name of artificial unification in the Middle East, a land of incontestable religious, cultural and ethnic diversity of people that "[exhibits] no uniformity, unity, or continuity in their cultural, ethnic, or linguistic attributes to warrant the monolithic appellation of 'Arab World.",27

Many philosophers and intellectuals have adhered to this Francophone-Phoenician Lebanese form of identification, such as the accomplished Lebanese-Maronite Charles Corm. He was the main thinker behind the 'Young Phoenicians' movement that rejected the idea that Lebanon was part of a larger an Arab region and linked Lebanese blood back to its Phoenician heritage. Educated in a Francophone Jesuit institution, Corm came to value the Western way of life, embracing French culture and cosmopolitism and looking poorly upon Arab nationalists who completely rejected any form of European intervention or influence. He is particularly famous for his French poem La Montagne Inspirée (translated into The Sacred Mountain), for which he

\footnotetext{
${ }^{23}$ Sélim Abou, Arabic-French Bilingualism in Lebanon, 284

${ }^{24}$ Sélim Abou, Arabic-French Bilingualism in Lebanon, 46

${ }^{25}$ Deanna Ferree Womack, Lubnani, Libanais, Lebanese: Missionary Education, Language Policy and Identity Formation in Modern Lebanon, 7

${ }^{26}$ Joseph, Language and Identity, 200

${ }^{27}$ Salameh, Language, Memory and Identity in the Middle East, xii
} 
won the Edgar Allan Poe International Prize of Poetry in 1934. The Lebanese Christians and followers of the Young Phoenicians movement saw it as "a veritable epopee, the stuff of legends, evoking in living poetic form all the hopes, the emotions, the disappointments, and the yearnings and memories of the people." ${ }^{28}$ The poem expresses the love of the homeland, Mount Lebanon, embracing its Christian, Francophone and Phoenician roots. The passage "So then the old Lebanon / Like a cathedral / Whose statues / Were sadly silenced / Since the Middle Age / Awaken suddenly!" refers to the link between Mount Lebanon and Catholicism, while the final stanza of the poem "Since these same words of the lips of France / I have taken them trembling from an impassioned heart / These words have a taste, on my lips, where my suffering smiles / From Lebanese kisses" embraces the strong ties between the Maronites and the French. ${ }^{29}$ Moreover, the passage "Tongue of the Phoenicians, my Lebanese tongue / Whose letter is voiceless under the sealed tombs / Tongue of the Golden Age, you were the genesis / Of all the alphabets" ${ }^{30}$ celebrates the greatness of the Phoenicians, the civilization Corm sees as the true forefathers of the Lebanese. ${ }^{31}$ For Charles Corm, as well as for many other Maronite Christians, the French language was an outlet to express this original, diverse and new Middle Eastern identity that they felt was not represented in more Arab or Muslim circles.

\section{Anglophone Influence in Lebanon}

While French gained an extremely significant cultural and symbolic status in Lebanese society, the role of the English language was also on the rise in the $20^{\text {th }}$ century thanks to Protestant missionary schools. While French was mostly popular among Maronites, English was more present in Orthodox Christian circles. The American University of Beirut, in particular, played a very significant role in increasing the value of Anglophone and American culture in the region, as it attracted not only the Lebanese elite, but also students from all over the Middle East. Along with the increase in globalization and the rise of the United States as a global hegemonic power, English naturally gained more influence as the language of international business and diplomacy in the second half of the $20^{\text {th }}$ century. This rise of English came at the expense of French influence in Lebanon, especially following the full Lebanese independence from France in 1943 and the gradual weakening of France compared to the American superpower in the following decades.

Although American Protestants founded many prominent missionary schools similarly to the French, "American missionary policies were not directly tied to their government's political interests, as was the case with French missionaries." 32 American Protestants were mostly looking to spread the American language and religion, whereas the French saw the installation of Catholic missionary schools as a means of strengthening political relations with Lebanon, the haven for the Catholic religion in the predominantly Muslim region. It is for this reason that, in order to attract more students in terms of diversity and numbers, American Protestant

\footnotetext{
${ }^{28}$ Salameh, Charles Corm, 112

${ }^{29}$ Charles Corm, The Sacred Mountain, 16, 106

${ }^{30}$ Charles Corm, The Sacred Mountain, 41

Charles Corm, The Sacred Mountain, 106

${ }^{32}$ Deanna Ferree Womack, Lubnani, Libanais, Lebanese: Missionary Education, Language Policy and Identity Formation in Modern Lebanon, 8
} 
missionary schools were more willing to promote the instruction of Vernacular Arabic, the language that speaks the most to the common Lebanese people. ${ }^{33}$

\section{The Rise of Arab Nationalism}

Although Western powers very successfully promoted their language and religion in Lebanon with many positive responses from the Lebanese people, their role in the region was threatened and consequently weakened by the rise of the Arab Nationalism, a political movement that sought to unite all the Arab people. Arab nationalists considered language, in this case Modern Standard Arabic, to be the unifying force in the Arab World and sought to centralize it in people's daily lives. They emphasized the usage of MSA to bring together various people who were religiously, culturally, and ethnically diverse, and promoted the idea that the Arab identity was superior to all other forms of ethno-religious identification by promoting a nationalist and secularist agenda, one that was very appealing due to its modernizing, anti-Western and anti-colonial message. ${ }^{34}$ The ultimate goal of Arab nationalism was the unity of all the Arab people in order to avoid losing wars to the imperialist and colonizing Western powers, notably the United States, Western Europe, and Israel. ${ }^{35}$

The Arab nationalist movement was embodied by intellectuals such as Sati' Al-Husri, an Ottoman-Syrian writer from Yemen, and Michel Aflaq, a Syrian Christian philosopher and co-founder of the Ba'ath political party. In the political sphere, it was the charismatic president of Egypt, Gamal Abdel Nasser (president from 1956 to 1970), who was the ultimate representation of Arab nationalist values. They were all extremely strong advocates for a uniquely Arab identity, for the usage of MSA in Middle Eastern society, and for the disregard of minority ethno-religious forms of identification in the name of unity and modernization. In Sati' al Husri's nationalist vision, for example, MSA was to be exclusively used since Vernacular Arabic did not speak to true Arab identity, and Arabic-speaking people were to be strictly considered Arab. This very famous passage by Sati' al Husri is a perfect demonstration of the Arab nationalist agenda:

Every Arab-speaking people is an Arab people. Every individual belonging to one of these Arabic-speaking peoples is an Arab. And if he does not recognize this, and if he is not proud of his Arabism, then we must look for the reasons that have made him take this stand. It may be an expression of ignorance; in that case we must teach him the truth. It may spring from an indifference or false consciousness; in that case we must enlighten him and lead him to the right path. It may result from extreme egoism; in that case we must limit his egoism. But under no circumstances, should we say: "As long as he does not wish to be an Arab, and as long as he is disdainful of his Arabness, then he is not an Arab." He is an Arab regardless of his own wishes. Whether ignorant, indifferent, undutiful, or disloyal, he is an Arab, but an Arab without consciousness or feeling, and perhaps even without conscience. ${ }^{36}$

Lebanese Arab Nationalists felt that Arab culture, which was to them the true essence of Lebanese culture, was being undermined and ignored due to the strong Western influence in Lebanon. Arab Nationalists saw France as a colonizing power seeking to exploit Lebanese land and resources for their own interest, and not as the cultural and

${ }^{33}$ Deanna Ferree Womack, Lubnani, Libanais, Lebanese: Missionary Education, Language Policy and Identity Formation in Modern Lebanon, 7

${ }^{34}$ Dawisha, Arab Nationalism in the 20th century, 42

${ }^{35}$ Dawisha, Arab Nationalism in the 20th century, 3

${ }^{36}$ Dawisha, Arab Nationalism in the $20^{\text {th }}$ century, 72 
political ally the Young Phoenicians saw them to be. To them, the sense of a cosmopolitan Mediterranean culture was a way for the French Catholics to maintain their power in the Middle East, a land they had absolutely no legitimate claim on. ${ }^{37}$ Although this movement was weaker in Lebanon due to the large number of Christians identifying with France and the Phoenician civilization, many Lebanese Muslims adhered to Pan-Arabism; they felt underrepresented in a country politically and culturally dominated by Francophone Lebanese Christians, and believed that Lebanon had succumbed to imperialism and needed to reconnect with its Muslim and Arab Middle Eastern neighbors.

Interestingly, missionary schools played a very important role in the rise of MSA and Arab nationalism in Lebanon. For example, in order to increase their competitiveness against American Protestant schools, French Catholic schools added Modern Standard Arabic to their curriculum to attract more students. ${ }^{38}$ Additionally, American Protestant Universities, in particular the AUB, was a breeding ground for Arab Nationalism and leftist ideas of anti-imperialism, with an emergence of a Greater Syrian identity among its students and the enthusiastic embrace of the importance of Modern Standard Arabic. ${ }^{39}$

Arab nationalists rejected Francophone and Anglophone influence in Lebanon for the sake of promoting Modern Standard Arabic, a factor that would connect them to other Arab countries. The rise of prominence of Modern Standard Arabic, in parallel to the undeniable influence of French and English in the region, eventually contributed to the substantial social tensions.

\section{Political \& Cultural Tensions between Christians \& Muslims in Lebanon}

Tensions between Christians and Muslims arose with the establishment of missionary schools. These schools led to Christian political, economic and culture dominance in Lebanon since they were associated with status and power. ${ }^{40}$ The large majority of Muslims, being unable to provide their children with this prestigious education, felt a strong divide with the Christians since there were fewer schooling resources and less acquisition of bilingualism in non-Christian schools. ${ }^{41}$ French was essential for economic and political advancement in $20^{\text {th }}$ century Lebanon, leading Lebanese Muslims to resent the Maronites and France; they believed that the French were responsible for their loss in status due to the Christian political and economic elite they were breeding. This divide "helped foster feelings of Arab nationalism and rejection of Western cultures and languages among certain (mainly Muslim) groups in Lebanon." 42

This antagonism is not theological. The strong sectarianism in the region is due to the different image each group has of what Lebanon is and should be. This disagreement is illustrated by the competing languages present in the country, since "the coexistence

\footnotetext{
${ }^{37}$ Nemer Frayha, Education and Social Cohesion in Lebanon, 6

${ }^{38}$ Deanna Ferree Womack, Lubnani, Libanais, Lebanese: Missionary Education, Language Policy and Identity Formation in Modern Lebanon, 12

${ }^{39}$ Deanna Ferree Womack, Lubnani, Libanais, Lebanese: Missionary Education, Language Policy and Identity Formation in Modern Lebanon, 13

${ }^{40}$ Youssef Courbage, Une enquête sur la pratique de la langue française au Liban, 3

${ }^{41}$ Sélim Abou, Arabic-French Bilingualism in Lebanon, 111

${ }^{42}$ Rula Diab, Political and Socio-Cultural Factors in Foreign Language Education-

The Case of Lebanon, 5
} 
in Lebanon of the Arabic and French languages presents itself as an immediate conflict that engages the personality of the Lebanese and divides their opinion." ${ }^{43}$ The two dominant religions in Lebanon identify with two distinct conceptions of civilization and mankind, the Christian being Western-oriented and the Muslim being Araboriented, as reflected by the usage of different languages by different groups of people: Lebanese Christians are usually the defenders of the French language, whereas Lebanese Muslims tend to identity more with the Arabic language. ${ }^{44}$ Citizens of Lebanon are therefore faced with the challenge of incorporating "parallel but politically incompatible varieties of ethno-linguistic identification," a phenomenon the political scientist Tristan Mabry refers to as "dinationalism." ${ }^{45}$ Since incorporating both is somewhat difficult or unnatural, the Lebanese often ended up identifying with either one or the other.

The ambiguity of the National Pact, the unwritten agreement of 1943 reached following Lebanese independence as a multi-confessional state, perfectly illustrates this confusing Lebanese identity. The pact establishes the Middle Eastern country as "a sovereign State with an Arab face," a vague definition that satisfies all ethnoreligious Lebanese communities in order to create a sense of unity in the diverse country. ${ }^{46}$ It also appoints key positions in government along sectarian lines and in proportion to the number of people per sect, leading to a political dominance of Maronite Christians followed by that of Sunni Muslims. ${ }^{47}$ The failure of the government's ambition to foster unity, however, is demonstrated by the multiple violent clashes that followed Lebanese independence, such as the 1958 conflict putting pro and anti-Nasserists at odds, and more importantly the Lebanese Civil War (19751990) that ravaged the country during fifteen years.

Politics in Lebanon is deeply associated with religion, and religious factors "[shape] motivations and attitudes towards a foreign language learning" in order to make a political statement through language. ${ }^{48}$ However, there are other factors that determine the choice of language in Lebanon as a good number of Muslims speak French and a growing number of Christians decide to stick to Arabic or monolingualism. Socioeconomic status also influences the usage of foreign languages; the bourgeois class of all ethno-religious communities views Western languages as the gateway to prestige and education, whereas more modest households lack the resources to adopt a bilingual lifestyle. ${ }^{49}$ Moreover, gender was historically another factor in foreign language learning dating back to the $19^{\text {th }}$ century: French, being perceived as more of a 'feminine language', led to a higher number of young girls being sent to missionary schools. ${ }^{50}$

As a result, whether as a question of religious background or socio-economic status, the disagreements in Lebanon regarding language have greatly contributed to an identity crisis which has profoundly impacted the modern reality of Lebanese society.

\footnotetext{
${ }^{43}$ Sélim Abou, Arabic-French Bilingualism in Lebanon, 14

${ }^{44}$ Sélim Abou, Arabic-French Bilingualism in Lebanon, 58, 78

${ }^{45}$ Mabry, The Levantine Review, "Arab Dinationalism"

${ }^{46}$ Nemer Frayha, Education and Social Cohesion in Lebanon, 6

${ }^{47}$ Esposito, Islam: the Straight Path, 218

${ }^{48}$ Rula Diab, Political and Socio-Cultural Factors in Foreign Language Education-

The Case of Lebanon, 9

${ }^{49}$ Bahous, Bacha, Nabhani, Multilingual educational trends and practices in Lebanon: A case study, 4, 10

${ }^{50}$ Deanna Ferree Womack, Lubnani, Libanais, Lebanese: Missionary Education, Language Policy and Identity Formation in Modern Lebanon, 11
} 


\section{8. $21^{\text {st }}$ Century and Trilingualism}

In the $21^{\text {st }}$ century, all three languages, Arabic, French and English, play very important roles in Lebanese intellectual, professional, and personal spheres. An increasing number of public and private schools are adopting a bilingual and even trilingual system, with a growing interest in English as the language of study:

Of the total number of 2,788 schools in Lebanon, 50.2 per cent are public and 49.8 per cent are private; 55.8 per cent of the schools have French as the medium of instruction (i.e., French is the first foreign language), 21.6 per cent (and increasing at a rapid rate) have English as the medium of instruction (i.e., English is the first foreign language), and 22.6 per cent have both French and English, one acting as the first foreign language and the other as a second foreign language. ${ }^{51}$

Although French remains more associated with Christian circles and Arabic with Muslim circles, educational inequalities and differences in bilingualism or trilingualism today are more related to socioeconomic inequalities rather than to religious sectarianism. ${ }^{52}$ Both the Christian and Muslim upper-class families prefer sending their children to Francophone or Anglophone schools for the sake of prestige and economic opportunity, since French is considered the language of culture and English the language of utility. ${ }^{53}$

With an incessantly globalizing world, English has gained the status of international language post-World War II and maintains its dominance in the world to this day in the fields of diplomacy, business, and technology. The number of Anglophone Lebanese speakers and institutions has therefore been on the rise since "anyone hoping to advance academically, socially or professionally must attain a certain level of proficiency in English." 54 This inevitably led to the decline in the importance of the French language and culture, since many young people view English in a more favorable light, as essential for success domestically and internationally. ${ }^{55}$ Consequently, the dominance of the English language in academia and the business world led to a lack of acquisition of Modern Standard Arabic among younger generations $^{56}$ They view MSA as tedious and unnecessary for social advancement and prefer to study foreign languages for intellectual and professional matters, which is very problematic in a country with MSA as its official language.

Although English seems to be the language gaining the most power in recent decades, French and Arabic still maintain a very important status. Lebanon is today known as a true 'trilingual' country with all three languages spoken and celebrated in different ways. Polyglotism in Lebanon is constantly evolving depending on political, economic, and cultural trends, both in Lebanon and globally, and will continue to evolve for the centuries to come.

\footnotetext{
${ }^{51}$ Bahous, Bacha, Nabhani, Multilingual educational trends and practices in Lebanon: A case study, 4

${ }^{52}$ Rula Diab, Political and Socio-Cultural Factors in Foreign Language Education-

The Case of Lebanon, 10

${ }^{53}$ Sélim Abou, Arabic-French Bilingualism in Lebanon, 300

${ }^{54}$ Rula Diab, Political and Socio-Cultural Factors in Foreign Language Education-

The Case of Lebanon, 8

${ }^{55}$ Rula Diab, Political and Socio-Cultural Factors in Foreign Language Education-

The Case of Lebanon, 7-8

${ }^{56}$ Hesham Shawish, BBC News, "Campaign to Save the Arabic Language in Lebanon"
} 


\section{Conclusion}

Language and identity define one another. In Lebanon, the close relationship between language and identity is very evident. The usage of a specific language in this multilingual nation is an indicator of one's identity, an identity that is especially related to one's religion and to one's political and cultural vision for Lebanon. Lebanon became a polyglot country as a result of multiple invasions and the spreading of foreign missionary education, giving Arabic, French and English important roles in Lebanon. Each of these three languages has its own role and image within Lebanese society, as some are more used by certain groups and during certain periods of time. Even though language is usually seen as a conveyor of culture, in Lebanon it is often used as a political tool to express one's beliefs.

A real identity crisis persists in Lebanon to this day, symbolic of an "unresolved conflict," both diplomatic and ideological. ${ }^{57}$ Beirut, for example, is clearly divided between Sunni, Shia, and Christian sectors, with disputes emerging not only between the pro or anti-Western but also between the pro and anti-Assad/Hezbollah Lebanese, the latter being the conflict that is bringing up the most political turmoil today in $21^{\text {st }}$ century Lebanon. This identity crisis, for many, seems impossible to resolve. The lack of cohesion in Lebanese society is so strong that there has been no official census in Lebanon since 1932 , making $21^{\text {st }}$ century Lebanese demographics completely unknown. ${ }^{58}$ The abundance of different influences, cultures, and ethno-religious groups is the cause of a very confused Lebanese identity, leading to the usage of other forms of identification before the national Lebanese one.

However, there might be a way to resolve the Lebanese identity crisis. Amin Maalouf, the celebrated Lebanese-French author, defies the traditional Lebanese sense of identity, or lack thereof, and adopts a more pluralistic approach by embracing and celebrating the multiple aspects of his personality and background instead of only choosing one. In his book In the Name of Identity, he proudly states: "What makes me myself rather than anyone else is the very fact that I am poised between two countries, two or three languages, and several cultural traditions. It is precisely this that defines my identity." 59 The sense of identity Maalouf describes here perfectly applies to $21^{\text {st }}$ century Lebanon, being a country of great diversity on all fronts rather than uniformity. It is by adopting Maalouf's view of a pluralistic identity that the Lebanese people from all backgrounds and ideologies can hopefully finally coalesce and reconcile with a common, unique, rich and vibrant 'Lebanese' identity, becoming in the process an example and an inspiration for other regions in conflict in the world.

\footnotetext{
${ }^{57}$ Waleed Ali, The Sydney Morning Herald, "Divided Lebanon has an Identity Crisis"

${ }^{58}$ Esposito, Islam: the Straight Path, 219

${ }^{59}$ Amin Maalouf, In the Name of Identity
} 


\section{REFERENCES}

Abou, Sélim. Arabic-French Bilingualism in Lebanon. Presses Universitaires De France, 1962.

Aly, Waleed. "Divided Lebanon Has an Identity Crisis." The Sydney Morning Herald. January 10, 2014. Accessed November/December, 2016.

Bahous, Rima, Nahla Nola Bacha, and Mona Nabhani. "Multilingual Educational Trends and Practices in Lebanon: A Case Study." Springer, December 9, 2011.

Corm, Charles. The Sacred Mountain. Beirut: La Revue Phénicienne, 1964.

Courbage, Youssef. "Une Enquête Sur La Pratique De La Langue Française Au Liban." Population (French Edition) 51, no. 6 (November/December 1996).

Dawisha, A. I. Arab Nationalism in the Twentieth Century: From Triumph to Despair. Princeton, NJ: Princeton University Press, 2003.

Diab, Rula. "Political and Socio-Cultural Factors in Foreign Language Education: The Case of Lebanon." Texas Papers in Foreign Language Education 5 (2000).

Esposito, John L. Islam: The Straight Path. 5th ed. New York, NY: Oxford UP, 2016. Print.

Ferree Womackn, Deanna. "Lubnani, Libanais, Lebanese: Missionary Education, Language Policy and Identity Formation in Modern Lebanon." Studies in World Christianity 18, no. 1 (2012).

Frayha, Nemer. "Education and Social Cohesion in Lebanon." Prospects XXXIII, no. 1 (March 2003).

Joseph, John E. Language and Identity: National, Ethnic, Religious. Palgrave Macmillan, 2004.

Maalouf, Amin. In the Name of Identity: Violence and the Need to Belong. New York: Arcade, 2001.

Mabry, Tristan. "Arab Dinationalism." The Levantine Review 2, no. 1 (2013): 27-53.

Salameh, Franck. Charles Corm: An Intellectual Biography of a Twentieth-Century Lebanese "Young Phoenician" Lanham: Lexington Books, 2015.

Salameh, Franck. Language, Memory, and Identity in the Middle East: The Case for Lebanon. Lanham, MD: Lexington Books, 2010.

Shawish, Hesham. "Campaign to save the Arabic Language in Lebanon." BBC. June 24, 2010. Accessed November 30, 2016. 